\title{
Natural Radioactivity Concentration and Radiological Evaluation in Soil Samples Around Dangote Cement Factory Ibese, Ogun State, Nigeria
}

\author{
Olatunji Kehinde Olanipekun, Bamidele Lateef \\ Department of Science Laboratory Technology, Osun State College of Technology, Esa-Oke, Nigeria
}

Email address:

Bamlat15@gmail.com (B. Lateef)

\section{To cite this article:}

Olatunji Kehinde Olanipekun, Bamidele Lateef. Natural Radioactivity Concentration and Radiological Evaluation in Soil Samples Around Dangote Cement Factory Ibese, Ogun State, Nigeria. Nuclear Science. Vol. 5, No. 2, 2020, pp. 22-26. doi: 10.11648/j.ns.20200502.12

Received: March 21, 2020; Accepted: April 10, 2020; Published: August 27, 2020

\begin{abstract}
Background: Natural-occurring radioactive materials (NORMs) provide significant sources of human exposure to ionizing radiation but in certain cases, anthropogenic activities, like mining, have produced wastes that contain radiation above background levels in the environment, a situation that is of great concern for radiation protection. Around Dangote cement factory both mining and production have been on-going for some years, therefore there is need to evaluate the extent of the possible risk of the radionuclides to the health of the population in this study area. Measurements of radioactivity concentrations were carried out around Dangote Cement Factory Ibese. Samples of surface soil were measured using gammaray spectroscopy Nal (TI) scintillation detector. Results: Measurements showed that activity concentrations ranged from $18.33+1.91 \mathrm{Bqkg}^{-1}$ to $29.14 \pm 4.4 .2 \mathrm{Bqkg}^{-1}$, with an average of $23.40 \mathrm{Bqkg}^{-1}$ for $\left({ }^{238} \mathrm{U}-{ }^{226} \mathrm{Ra}^{2}, 10.93 \pm 5.43 \mathrm{Bqkg}^{-1}\right.$ to $21.52 \pm 2.16$ $\mathrm{Bqkg}^{-1}$ with an average of $16.50 \mathrm{Bqkg}^{-1}$ for ${ }^{232} \mathrm{Th}$, and $291.78 \pm 15.50 \mathrm{Bqkg}^{-1}$ to $338.60 \pm 3.922 \mathrm{Bqkg}^{-1}$ with an average of 314.11 $\mathrm{Bqkg}^{-1}$ for ${ }^{40} \mathrm{~K}$. Similarly, the absorbed dose ranged from $28.63 \mathrm{nGy} / \mathrm{h}$ to $38.24 \mathrm{nGy} / \mathrm{h}$ with an average of $33.14 \mathrm{nGy} / \mathrm{h}$. The calculated annual effective dose ranged from $0.035 \mathrm{mSv} / \mathrm{y}$ to $0.047 \mathrm{mSv} / \mathrm{y}$ with an average of $0.040 \mathrm{mSv} / \mathrm{y}$. Conclusions: The average value of Radioactivity concentrations obtained for ${ }^{238} \mathrm{U},{ }^{232} \mathrm{Th}$ and ${ }^{40} \mathrm{~K}$ are lower than the corresponding global values reported in UNSCEAR publication. The calculated absorbed dose and annual effective dose values are also less than the recommended safe levels.
\end{abstract}

Keywords: Radioactivity Concentration, Spectroscopy, Dangote Cement Factory, Ibese

\section{Introduction}

Man since formation of the earth is exposed to many diverse sources of radiations. These sources may be natural or as a result of human activities. The radiation from natural sources include cosmic radiation, external radiation from radionuclide in earth's crust and internal radiation from radionuclide's inhaled or ingested and retained in the body [1]. According to the United Nations Scientific Committee on effects of Atomic Radiation Report (UNSCEAR), the greatest contribution to mankind's exposure comes from natural background radiation [2]. Gamma radiations emitted from Natural Occurring Radioactive Materials (NORMS) such as uranium $\left({ }^{238} \mathrm{U}\right)$, thorium $\left({ }^{232} \mathrm{Th}\right)$, and potassium $\left({ }^{40} \mathrm{k}\right)$ are generally known as terrestrial background radiation and is the main external of irradiation of the human body. External exposures outdoors arise from terrestrial radionuclides present at trace levels in all soils. The specific levels are related to the geological and geographical conditions of those areas. Higher radiation levels are associated with igneous rock such as granite and lower levels with sedimentary rocks [2]. Also, the presence of NORMS in soil generally originates from the disintegrating rocks that are carried to soil by rain and flows [3]. Cement main constituents are clay, shale and limestone. These constituents of cement are found in the soil. Kim in 1995 reported the presence of radionuclide of thorium's and uranium series in limestone and also same traces concentration of thorium, uranium and potassium in black shale in some regions [4]. Radiation from soil environment is one of the main source of exposure to humans hence it is important to know the distribution of gamma radiation from radionuclide's such as ${ }^{40} \mathrm{~K}$ and also from ${ }^{238} \mathrm{U}$ 
and ${ }^{232} \mathrm{Th}$ series [5]. The radionuclide's in limestone and shale and their overlying soil materials can become pollutant when present in greater levels than the natural concentrations. These higher concentrations in radionuclide in limestone and shale or cement raw materials may be detrimental to humans' health [6]. The presence of these radionuclides in different food crops grown on the soil around the cement factory may also constitute a health hazard. Gene damage is the greatest threat of radionuclide [7].

This study, assess the radioactivity concentrations in soil samples around Dangote Cement factory in Ibese, Ogun State, Nigeria and evaluate radiological hazard indices. The results obtained were compared with the previous results of some countries around the world.

\section{Materials and Methods}

Study Area. Ibese is locate in Yewa North local government Area, Egbado North, area of Ogun State, Southwest Nigeria. Its geographical coordinates are $6^{0} 58^{1} 0^{11}$ North, $3^{0} 2^{1} 0^{11}$ Exact. The people living these are predominantly farmers and traders. It's about $35 \mathrm{~km}$ from Abeokuta the Ogun State Capital and 45km from Lagos.

The geology of Ibese and environs consists of Ewekoro formation which is marine and paleocene age. It consists of a limestone unit several meters in thickness which is overlain by a shale unit almost three times as thick as the limestone. In terms of regional geology, the study area belongs to the Eastern part of Dahomey Basin extending from the Volta Delta (South eastern Ghana) to the western flank of the Niger Delta in Nigeria [8]. Dangote cement factory is situated about a kilometer away from Ibese town.

\subsection{Sample Collection and Processing}

Samples were collected randomly during dry season of 2018. After the soil position where the soil samples are to be taken was determined, the ground was cleared of stones pebbles, vegetation and roots $2 \mathrm{~kg}$ of soil sample were collected from a soil positioned about $10 \mathrm{~cm}$ below the soil surface. A total of fifteen soil samples were taken and placed in a coded polythene bag. The fifteen soil samples were taking to the laboratory where they were first air dried and then grounded in to a fine powder of $200 \mu \mathrm{m}$ in size after been oven dried at a temperature of $105^{\circ} \mathrm{C}$ for 8 hours. $100 \mathrm{~g}$ of the homogeneous soil samples were then packed in polythene plastic, weighed and carefully sealed and stored for at least 4 weeks before counting to allow time for ${ }^{238} \mathrm{U}$ and ${ }^{232} \mathrm{Th}$ to reach equilibrium with their respective radionuclide daughters'.

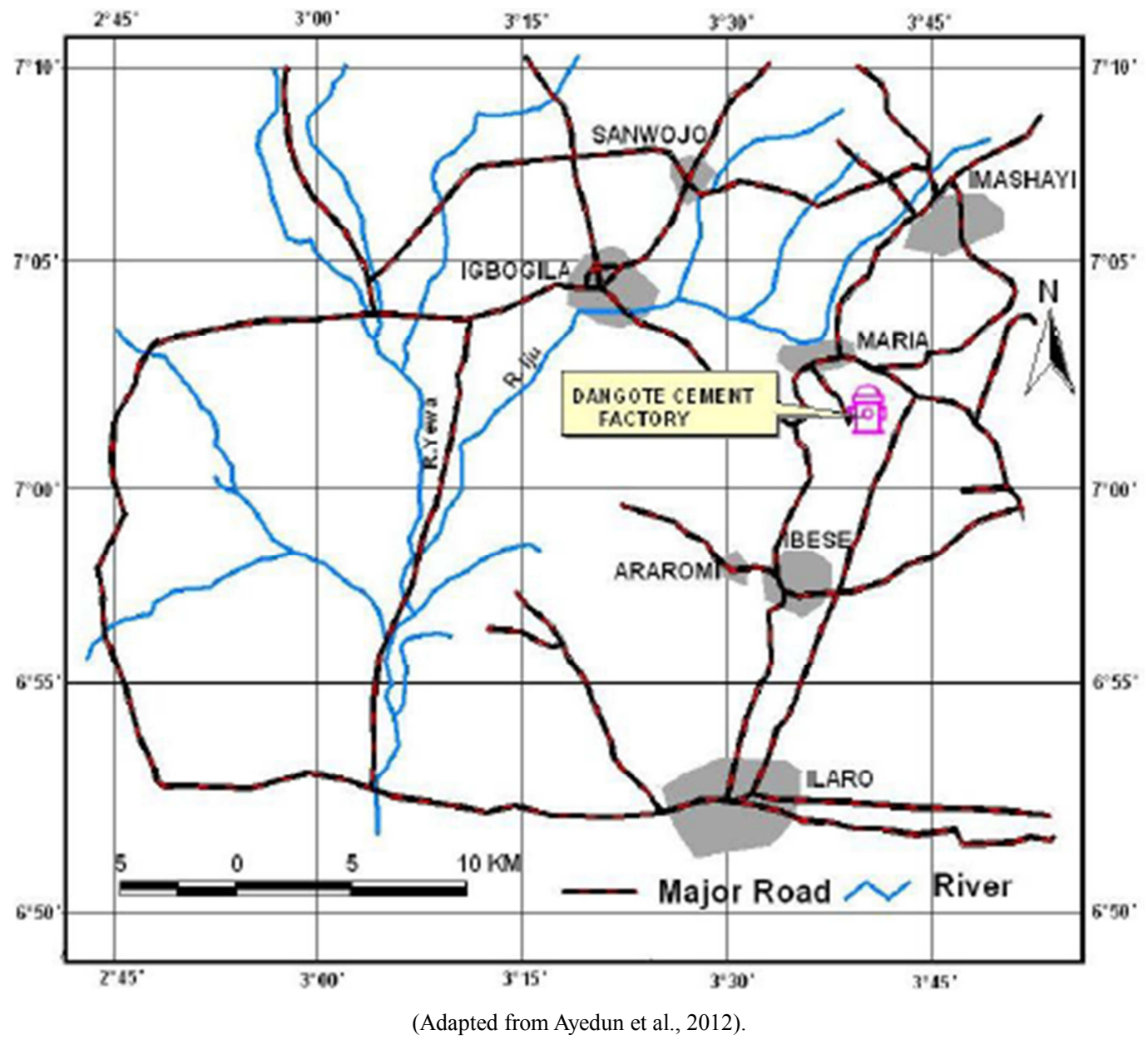

Figure 1. Location map showing the study area. 


\subsection{Experimental and Calibration}

Using a well calibrated Nal (TI) and well shielded detector couple to a computer resident quantum MCA2100R Multichannel analyzer for analyzer for 36000s.

An empty container under identical geometry was also counted for the same time. The $1460 \mathrm{KeV}$ gamma- radiation of $40 \mathrm{k}$ was used to determine the concentration of ${ }^{40} \mathrm{k}$ in the sample. The gamma transition energy of $1764.5 \mathrm{KeV}{ }^{214} \mathrm{~B}_{\mathrm{I}}$ was used to determine the concentration of ${ }^{238} \mathrm{U}$ while the gamma transition energy of $2614 \mathrm{KeV}{ }^{20} \mathrm{Th}$ was used to determine the concentration of ${ }^{232} \mathrm{Th}$ while $137 \mathrm{Cs}$ was detected by its $661.6 \mathrm{KeV}$ gamma transition. The efficiency calibration of the detector was done using a reference standard dose, associated with the cement production. The energy calibration was also performed by using the peaks of the radionuclide's present in the standard sources. The channel scale was then converted to an energy scale. This produces energy calibration curve i.e energy versus channel.

The activity concentration of the radionuclides in the samples was calculated after decay correction using the expression:

$$
\mathrm{A}_{\mathrm{C}}=\frac{N_{\text {sam }}}{F_{E . \mu(E) T_{C M_{\text {sam }}}}}
$$

Where $A_{C}$ is the activity concentration of the radionuclides in $\mathrm{Bq} / \mathrm{kg}, \mathrm{M}_{\mathrm{san}}$ is the mass sample $(\mathrm{kg}), \mathrm{N}_{\mathrm{sam}}$ is the sample net count in peak range, $\mathrm{F}_{\mathrm{E}}$ is the gamma emission probability, $\mu$ (E) is the photo peak efficiency and $T_{C}$ is the counting time. The minimum detectable activity (MDA) for each radionuclide ${ }^{238} \mathrm{U},{ }^{232} \mathrm{Th}$ and ${ }^{40} \mathrm{k}$ was calculated using the equation:

$$
\mathrm{MDA}=\frac{1.645 \sqrt{N B}}{F_{E \mu(E) T_{C . M}}}
$$

Where 1.645 is the coverage factor at $95 \%$ confidence level, $\mathrm{N}_{\mathrm{B}}$ is the background count at the region of interest, $\mathrm{T}_{\mathrm{C}}$ is the counting time, $\mathrm{F}_{\mathrm{E}}$ is the gamma emission probability, $\mu$ (E) is the photopeak efficiency and $M$ is the mass of the sample. The MDA for each radionuclides were calculated as $0.30 \mathrm{~Bq} / \mathrm{kg}$ for ${ }^{238} \mathrm{U}$, for $0.12 \mathrm{~Bq} / \mathrm{kg}$ for ${ }^{226} \mathrm{Ra}, 0.11 \mathrm{~Bq} / \mathrm{kg}$ for ${ }^{232} \mathrm{Th}$ and $0.90 \mathrm{~Bq} / \mathrm{kg}$ for ${ }^{40} \mathrm{~K}$. respectively.

\subsection{Dose Rate Calculation}

The absorbed dose rates at $1 \mathrm{~m}$ above the ground are calculated by converting the activity concentration of ${ }^{238} \mathrm{U}$, ${ }^{232} \mathrm{Th}$ and ${ }^{40} \mathrm{~K}$ into dose by using the formula (UNSCEAR2000) below.

$$
\mathrm{D}\left(\mathrm{nGyh}^{-1}\right)=0.0427 \mathrm{~A}_{\mathrm{U}}+0.043 \mathrm{~A}_{\mathrm{K}}+0.662 \mathrm{~A}_{\mathrm{Th}}
$$

Where $A_{k}, A_{u}$ and $A_{T h}$ are activity concentration of $K, U$ and $\mathrm{Th}$ in each sample respectively

\subsection{The Annual Effective Dose Rate Calculation}

The annual effective dose was calculated from the absorbed dose rate by applying the dose conversion factor of $0.7 \mathrm{SvGy}^{-1}$ and an outdoor occupancy factor of 0.2 recommended by UNSCEAR [2]. Thus, annual effective dose was obtained using equation:

Annual Effective Dose Rate $(\mathrm{AEDR})=\mathrm{D}\left(\mathrm{nGyh}^{-1}\right) \times 8760$ (hy $^{-}$
$\left.{ }^{1}\right) \times 0.2 \times 0.7 \mathrm{SvGy}^{-1} \times 10^{3}$

$$
\left.{ }^{1}\right) \times 0.2 \times 0.7 \mathrm{SvGy}^{-1} \times 10^{3}
$$

Where $\mathrm{D}$ is the absorbed dose rate in air and this calculation takes into account that the people spend $20 \%$ of their time outdoors.

\subsection{External Hazard Index $H_{E X}$}

The external hazard index $\mathrm{H}_{\mathrm{ex}}$ is an assessment of the hazard of the natural gamma radiation. $\mathrm{H}_{\mathrm{ex}}$ for samples in this study was calculated using equation defined by Ghazwa et al., [9].

$$
\mathrm{H}_{\mathrm{ex}}=\frac{C R a}{370}+\frac{C T h}{259}+\frac{C K}{4810} \leq
$$

Where $\mathrm{C}_{\mathrm{Ra}}, \mathrm{C}_{\mathrm{Th}}$ and $\mathrm{C}_{\mathrm{K}}$ are the activity concentrations of ${ }^{226} \mathrm{Ra},{ }^{232} \mathrm{Th}$ and ${ }^{40} \mathrm{~K}$ in $\mathrm{Bq} / \mathrm{kg}$ respectively. The maximum value of $\mathrm{H}_{\mathrm{ex}}$ equal to unity corresponds to the upper limit of $\operatorname{Ra}_{\mathrm{eq}}(370 \mathrm{~Bq} / \mathrm{kg})$.

\subsection{Radium Equivalent Activity ( $\left.R a_{e q}\right)$}

$\mathrm{Ra}_{\mathrm{eq}}$ is used to assess the gamma radiation hazards associated with materials that contain in ${ }^{226} \mathrm{Ra},{ }^{232} \mathrm{Th}$ and ${ }^{40} \mathrm{~K}$. It is assumed that $1 \mathrm{~Bq} / \mathrm{kg}$ of ${ }^{226} \mathrm{Ra}, 0.7 \mathrm{~Bq} / \mathrm{kg}$ of ${ }^{232} \mathrm{Th}$ and 1.3 of ${ }^{40} \mathrm{~K}$ produces the same gamma radiation dose rates. The $\mathrm{Ra}_{\mathrm{eq}}$ is given as:

$$
\mathrm{Ra}_{\mathrm{eq}}=\mathrm{C}_{\mathrm{Ra}}+\left(1.43 \mathrm{C}_{\mathrm{Th}}\right)+\left(0.077 \mathrm{C}_{\mathrm{K}}\right)
$$

Where $\mathrm{C}_{\mathrm{Ra}}, \mathrm{C}_{\mathrm{Th}}$ and $\mathrm{C}_{\mathrm{K}}$ are the average activity concentrations of ${ }^{226} \mathrm{Ra},{ }^{232} \mathrm{Th}$ and ${ }^{40} \mathrm{~K}$ in $\mathrm{Bq} / \mathrm{kg}$ respectively.

\subsection{Calculation of Lifetime Cancer Risk}

Lifetime cancer risk (ELCR) was calculated using equation below

\section{$\mathrm{ELCR}=\mathrm{AED} X \mathrm{XL} X \mathrm{RF}$}

Where DL is the life expectancy (The life expectancy for Nigeria in 2019 is 54.49) and RF is the risk factor $\left(\mathrm{Sv}^{-1}\right)$, it is fatal cancer risk per Sievert. For stochastic effects from low dose background radiation, ICRP 103 suggested the value of 0.057 for the public exposure [10].

\section{Results and Discussion}

Activity concentrations, external annual effective dose and absorbed dose rate of are soil samples shown in the table 1. The corresponding comparisons with similar studies carried out in other countries are displayed in table 2.

Activity concentrations in the soil samples measured in this study varied from $18.343 \mathrm{qKg}^{-1}$ to $29.14 \mathrm{BqKg}^{-1}$ with an average value of $23.4 \mathrm{BqKg}^{-1}$ as indicated in table 1 . 
Activity concentrations of ${ }^{232} \mathrm{Th}$ also ranged from $10.93 \mathrm{BqKg}^{-1}$ to $29.14 \mathrm{BqKg}^{-1}$ with an average of $16.47 \mathrm{BqKg}^{-}$ 1. The activity concentrations of ${ }^{40} \mathrm{k}$ varied from 291.78 $\mathrm{BqKg}^{-1}$ to $338.60 \mathrm{BqKg}^{-1}$ with an average of $314.11 \mathrm{BqKg}^{-1}$. The average values of activity concentrations of $238 \mathrm{U}$, $232 \mathrm{Th}$ and $40 \mathrm{~K}$ are lower than the $40 \mathrm{BqKg}^{-1}$ for both ${ }^{238} \mathrm{U}$ and ${ }^{232} \mathrm{Th}$ and $370 \mathrm{BqKg}^{-1}$ for $40 \mathrm{~K}$ recommended by
UNSCEAR (2000). It should be noted that despite the activity concentrations not higher than the recommended limit, they varied from one location to other as reported by UNSCEAR, (1993).

These average activity concentrations are found to be lower compared to values obtained elsewhere in Nigeria and in other countries in African. See table 2.

Table 1. Activity Concentrations (in Bq/kg) and absorbed dose rate and annual effective dose in $n G y h^{-1}$ and $\mathrm{mSv} / \mathrm{y}$ respectively.

\begin{tabular}{|c|c|c|c|c|c|}
\hline Sample & K-40 & U-238 & Th-232 & Absorbed & Annual \\
\hline & $\left(\mathrm{Bqkg}^{-1}\right)$ & $\left(\mathrm{Bqkg}^{-1}\right)$ & (Ra 228) & dose & Effective \\
\hline & & & $\left(\mathrm{Bqkg}^{-1}\right)$ & $\left(\mathrm{nGyh}^{-1}\right)$ & Dose $(\mathrm{mSv} / \mathrm{y})$ \\
\hline A1 & $302.16 \pm 30.01$ & $22.19 \pm 3.01$ & $19.13 \pm 2.08$ & 28.63 & 0.035 \\
\hline A2 & $300.09 \pm 60.16$ & $20.61 \pm 6.40$ & $10.93 \pm 5.43$ & 28.64 & 0.035 \\
\hline A3 & $321.38 \pm 45.07$ & $22.13 \pm 4.95$ & $18.42 \pm 3.16$ & 34.75 & 0.043 \\
\hline A4 & $326.37 \pm 30.10$ & $18.35 \pm 1.91$ & $14.03 \pm 3.24$ & 30.56 & 0.037 \\
\hline A5 & $308.22 \pm 47.03$ & $28.97 \pm 3.57$ & $15.22 \pm 1.38$ & 30.52 & 0.037 \\
\hline A7 & $338.60 \pm 39.22$ & $26.05 \pm 5.19$ & $14.13 \pm 1.09$ & 34.70 & 0.043 \\
\hline A8 & $312.61 \pm 22.15$ & $22.21 \pm 2.37$ & $15.42 \pm 2.33$ & 32.61 & 0.040 \\
\hline A9 & $300.14 \pm 25.86$ & $23.13 \pm 4.20$ & $14.39 \pm 2.40$ & 31.90 & 0.039 \\
\hline A10 & $320.48 \pm 39.28$ & $21.20 \pm 5.28$ & $18.18 \pm 3.34$ & 34.10 & 0.042 \\
\hline A11 & $334.68 \pm 25.01$ & $21.32 \pm 1.40$ & $16.24 \pm 2.38$ & 33.61 & 0.041 \\
\hline A12 & $308.94 \pm 16.20$ & $24.21 \pm 3.12$ & $20.01 \pm 1.06$ & 36.25 & 0.044 \\
\hline A13 & $291.78 \pm 27.03$ & $26.62 \pm 2.13$ & $21.52 \pm 2.16$ & 37.50 & 0.046 \\
\hline A 15 & $308.98 \pm 21.14$ & $24.21 \pm 2.22$ & $16.24 \pm 2.24$ & 33.88 & 0.041 \\
\hline
\end{tabular}

Table 2. Comparison of average activity concentrations with these of similar studies carried out in Africa.

\begin{tabular}{|c|c|c|c|c|}
\hline${ }^{238} \mathbf{U}$ & ${ }^{232} \mathrm{Th}$ & ${ }^{40} \mathbf{K}$ & Country & References \\
\hline 2.38 & 32.36 & 383.8 & Nigeria & Abdulahi et al., [11] \\
\hline 2.39 & 52.0 & 390.9 & Nigeria & Abdulkarim et al.,[12] \\
\hline 55.3 & 26.4 & 505.1 & Nigeria & Ademola et al., [13] \\
\hline 8.37 & 11.4 & 232.7 & Sudan & Sam et al., [14] \\
\hline 15.2 & 26.9 & 157.1 & Ghana & Faanu et al., [15] \\
\hline 13.6 & 24.2 & 162.1 & Ghana & Faanu et al., [16] \\
\hline 40.1 & 29.4 & 217.0 & Cameroon & Dallou et al., [17] \\
\hline 47.28 & 27.26 & 302.97 & Nigeria & Isola \& Moni [18] \\
\hline 23.4 & 16.2 & 314.6 & Nigeria & Present Study \\
\hline
\end{tabular}

The absorbed dose calculated ranged from $28.63 \mathrm{nGg} / \mathrm{h}$ to $38.24 \mathrm{nGg} / \mathrm{h}$ with a mean of $33.14 \mathrm{nGy} / \mathrm{h}$ also the values of annual effective dose varied from $0.035 \mathrm{mSv} / \mathrm{y}$ to $0.047 \mathrm{mSv} / \mathrm{y}$ with an average of $0.04 \mathrm{mSv} / \mathrm{y}$. However, comparing the results with world wide data, the obtained value was lower than $6 \mathrm{nGyh}^{-1}$ reported by UNSCEAR in 2000 .

Table 3. The radium equivalent $\left(R a_{e q}\right)$, the external hazard $\left(H_{e x}\right)$ and excess lifetime cancer risk (ELCR) of the soil samples.

\begin{tabular}{|c|c|c|c|}
\hline Locations & Radium & External & Excess Lifetime \\
\hline & Equivalent Activity & Hazard index $\left(\mathrm{H}_{\mathrm{ex}}\right)$ & Cancer risk $\left(\mathrm{Sv}^{-1}\right)$ \\
\hline & $\mathrm{Ra}_{\mathrm{eq}}(\mathrm{Bq} / \mathrm{kg})$ & 0.195 & $1.08 \times 10^{-4}$ \\
\hline A1 & 74.12 & 0.159 & $1.08 \times 10^{-4}$ \\
\hline $\mathrm{A} 2$ & 64.50 & 0.197 & $1.34 \times 10^{-4}$ \\
\hline A3 & 74.80 & 0.197 & $1.34 \times 10^{-4}$ \\
\hline A3 & 74.80 & 0.172 & $1.15 \times 10^{-4}$ \\
\hline A4 & 63.54 & 0.201 & $1.15 \times 10^{-4}$ \\
\hline A5 & 74.46 & 0.187 & $1.18 \times 10^{-4}$ \\
\hline A6 & 65.02 & 0.195 & $1.34 \times 10^{-4}$ \\
\hline A7 & 72.32 & 0.184 & $1.24 \times 10^{-4}$ \\
\hline A8 & 68.33 & 0.180 & $1.21 \times 10^{-4}$ \\
\hline A9 & 66.81 & 0.194 & $1.30 \times 10^{-4}$ \\
\hline A10 & 71.86 & 0.196 & $1.27 \times 10^{-4}$ \\
\hline A11 & 70.31 & 0.221 & $1.37 \times 10^{-4}$ \\
\hline A12 & 76.60 & 0.221 & $1.43 \times 10^{-4}$ \\
\hline A13 & 79.85 & & \\
\hline
\end{tabular}


Relative contribution to dose due to ${ }^{40} \mathrm{~K}$ was $88.7 \%$ followed by the contribution of dose to ${ }^{238} \mathrm{U}$ and ${ }^{232} \mathrm{Th}$ as $6.6 \%$ and $4.6 \%$ respectively. The estimated values of $\mathrm{Ra}_{\mathrm{eq}}$ in the present study ranged from 63.54 to $80.90 \mathrm{Bqkg}^{-1}$ are lower than the recommended maximum value of $370 \mathrm{Bqkg}^{-1}$ by UNSCEAR. The external radiation hazard index $\left(\mathrm{H}_{\mathrm{ex}}\right)$ calculated ranged from 0.159 to 0.221 which are lower than upper limit of unity. However, the value of this index must be less than unity in order to keep the radiation hazard insignificant. The estimated values of excess lifetime cancer risk (ELCR) for all the samples from Table 3 ranged from $1.08 \times 10^{-4}$ to $1.46 \times 10^{-4}$ which is lower than world average of $2.9 \times 10^{-4}$ [19].

\section{Conclusion}

In the present study, the results indicate that the natural radioactivity concentrations of ${ }^{40} \mathrm{~K},{ }^{232} \mathrm{Th}$ and ${ }^{238} \mathrm{U}$ are relatively lower than the allowable limits recommended by UNSCEAR publication. The obtained results of absorbed dose rate, annual effective dose were found lower than recommended safety limits. Although the result in this study pose not treat to workers and people in the surrounding, it indicated the existence of radioactive materials in the environments where such activities are taking place. Also the ranged value of $\mathrm{Ra}_{\mathrm{eq}}$ activity and external health hazard index values were found to be lower than recommended safe limit values, this study still made available data helpful for future evaluations, in case gross contamination of the area.

\section{References}

[1] Jibiri N. N, Adewole O. O, Eguujobi K. A (2010). Variation of mean radiation dose with distance of sites proximal to Purechem Cement factory, Onigbedun, Ogun State, Nigeria. The Pacific Journal of Science and Technology, 11 (2): 671673, 2010.

[2] UNSCEAR. Exposure from natural radiation sources United Nations Scientific. Committee on the Effect of Atomic Radiation Report to the General Assembly New York, USA, 2000 .

[3] Ramasamy V, Suresh G, Meena Kshisunder am V, Gajendran $\mathrm{V}$. "Evaluation of natura 1 radionuclide Content in river sediments and excess lifetime cancer risk due to gamma radioactivity”. Res. J Enu Earth Sa; 1: 6-10, 2009.

[4] Kim, Y, " Aquifer mineralogy and natural radionudides in groundwater. GCAGS Transactions", Vol. 45. 10.1306L2 DC 40AD4-OE47-IID7-8643000102 (18650), 1995.

[5] Abusini, M. K., Al-Ayasreh and J., Al-Jundi.” Determination of Uranium, thorium and potassium activity concentrations in soil cores in Arabia Valley", Jordan Radiat Protection. Dosim $10.1093 / \mathrm{rpd} / \mathrm{ncm} 327,2007$.

[6] Gbadebo A. M., Amos A. J. "Assessment of Radionudide, Polutants in bedrock and soil from Ewekoro Cemenet factory, Southwest Nigeria". Asian Jornal of Applied Science, 2010.
[7] Taskin H, Karayos M, Ay P, Topozoglu A, Hindiroglo S, Rarahssan G. "Radionuclide concentrations in soil and lifetime cancer risk due to gamma radioactivity in Kirklareli, Turkey". J Env. Radiat. 100: 49-53, 2009.

[8] Ayedun H, Oyyede R. T, Osinfade B. G et al.," Groundwater quality around new cemen $\mathrm{t}$ factory, Ibese, Ogun State, Southwest, Nigeria". African Journal of Pure and Applied Chemistry 6 (13): 219-223 2014.

[9] Ghazwa Alzubaidi, Fauziah B. S. Hamid and Abdul Rahman (2016). Assessment of natural radioactivity levels and radiation hazards in agricultural and virgin soil in the state of Kedah, North of Malaysia. The Scientific world Journal. Article ID6178103, http://dx.doi.org/10.1155/2016/6178103, 2016.

[10] ICRP. International Commission on Radiological Protection recommendation on radiation protection ICRP Report 103, Elsevier Ltd, 2007.

[11] Abdullahi M. A, Aliu S. O and Abdulkarim M.. "Gamma ray spectrometric analysis of naturally occurring radioactive materials (NORMS) in gold bearing soil using $\mathrm{NaI}$ (TI) technique.” J. Nat Sci. 4 (24) 2014.

[12] Abdulkarim M. S and Umar S. "An investigation of natural radioactivity around gold mining sites in Birnin Gwari North Western Nigeria". Res. J. Physical Sci. 1 (7): 20 -23 2013.

[13] Ademola A. K, Bello A. K and Adejumobi A, C. "Determination of natural radioactivity and hazard in soil samples in and around gold mining in Itagunmodi, Southwestern Nigeria. J. Radiat Resear, Appl Sci. 7 (3): 249-55, 2014.

[14] Sam A. K, and Awad Al-Geed A. M. "Radiological evaluation of gold mining activities in Ariab (Eastern Sudan)". Radiat Protect Dosim. 88 (4) 335-40, 2000.

[15] Faanu A, Ephraim J. H, and Darko E. O. "Assessment of public exposure to natural occurring radioactive materials from mining and mineral processing activities of Tarkwa Goldmine in Ghana”. Environ. Monit. Assess. 180: 15-29 2011.

[16] Faanu A, Adukpo O. K, Tettey-Larbi L et al., "Natural radioactivity levels in soils, rocks and water at a mining concession of Perseus gold mine and surrounding towns in central Region of Ghana". Springer Open Journal. 5: 98 DOI.101186/s40064-016-1716-5, 2016.

[17] Dallou G. B, Ngoa E. L, Ndjana N et al., "NORM measurements and radiological hazard assessment in the gold mining areas of Eastern Cameroon" Radiation Environment and Medicine. 6 (1): 21-28. in soil samples 2017.

[18] Isola G. A and Moni O. "Terrestrial gamma dose rates at Obajana cement factory in Kogi State, Nigeia." International Journal of Physics and Research. 5 (1): 33-40, 2015.

[19] Sharma, P et al., "Terrestrial gamma radiation dose measurement and health hazard along river Alaknanda and Ganges in India. Journal of Radiation Research and Applied Sciences. 2014. 